\title{
Taxonomy of Information Literacy Competencies
}

\author{
Theresa M. Vitolo \\ Department of Computer and Information \\ Science, Gannon University \\ Erie, PA, USA \\ vitoto@gannon.edu
}

\author{
Chris Coulston \\ School of Engineering and Engineering \\ Technology, Penn State University \\ Erie, $P A$, USA
}

Executive Summary

People living within an information culture possess different expectations and abilities with technology and digital systems because of their use of and exposure to technology. The first section of the paper reviews the situation of IT education and the need to address the shortage of professionals in the information-related professions. The shortage of IT professionals generates an attempt by educational institutions to develop programs that may or may not adequately address the shortage. Along with the shortage problem, concerns about information literacy are being raised among educators and professionals.

To model a connection between information literacy levels and IT education, Bloom's educational objective taxonomy is presented. In conjunction with Bloom's taxonomy, the five-component representation of information systems is presented. If an awareness of information systems enables one to be more information literate and if being more information literate enables one to handle IT situations better, then a representation connecting information systems and information literacy would offer insights to IT education. These two representations, Bloom's Taxonomy and the five-component representation of information systems, are combined to develop a relationship between growth in competency through education and the field of information systems.

The second section proposes an information literacy competency taxonomy, (ILC taxonomy). The ILC taxonomy expresses the relationship between growth in competency and understanding of information systems. Educational programs can be represented through the ILC taxonomy in terms of the degree of attention committed to the content characterized by each area of the ILC taxonomy.

The third section suggests how different programs can be expressed through the ILC taxonomy. Ultimately, the ILC taxonomy provides a tool for identifying what skills and behaviors within a spectrum of information literacy competencies individuals should be expected to possess, given an educational program.

Keywords: taxonomy, information literacy, education, information technology

Material published as part of this journal, either on-line or in print, is copyrighted by the publisher of the Journal of Information Technology Education. Permission to make digital or paper copy of part or all of these works for personal or classroom use is granted without fee provided that the copies are not made or distributed for profit or commercial advantage AND that copies 1) bear this notice in full and 2) give the full citation on the first page. It is permissible to abstract these works so long as credit is given. To copy in all other cases or to republish or to post on a server or to redistribute to lists requires specific permission and payment of a fee. Contact Editor@JITE.org to request redistribution permission.

\section{Overview of the Challenge of IT Education}

Over the last few years, an interesting set of events has developed as students, faculty, and professionals have wrestled with the growth of the information demands of our society. With every new technological advance in computing, academic institutions are faced with the challenge to provide the everyday world with competent individuals trained in identifying, building, and main- 
taining the technology. However, challenges often are accompanied by strife and confusion. Labor force statistics require these challenges to be addressed:

- Between 1994 and 2005, more than a million new computer scientists, computer engineers, systems analysts, and computer programmers will be needed (U.S. Department of Commerce, Office of Technology Policy, 1997);

- In the next 10 years, the demand for computer scientists, systems analysts, and programmers will double (U.S. Department of Commerce, 1998);

- The shortage of information technology workers costs American companies an estimated \$4.5 billion annually in reduced productivity (Information Technology Association of America, 1996);

- The lack of skilled information technology workers has been cited by executives as the most significant barrier to economic growth for their companies during the next year (Information Technology Association of America, 1996);

- The number of unfilled information technology positions in large and medium-size U.S. corporations neared 350,000 (Information Technology Association of America, 2000).

Within the arena of higher education, new schools, programs, and labels are being created to address the needs of the information society. Under the labels of "Informatics" or "Information Technology" or "Information Studies," universities are seeking to provide curriculums to equip majors with a necessary set of information-processing capabilities. Within these curriculums - or building along side them - are majors such as E-Commerce, Management Information Systems, or Computer Science, adding to the confusion for any new college-recruit. In addition to majors, many institutions are also providing certifications for a slue of information-processing ranks. While an increased interest in the fields associated with information studies is satisfying to professionals in the fields, often little sense, meaning, or congruency between these majors and certifications is being made.

Too often, labels and programs are being developed as fast as technology is changing. Simply because a proportion of corporations have job titles for "e-commerce developer" or "internet architect" (Tadjer, 1998) does not mean that universities need to offer a major in e-commerce or internet architecture. Individuals seek to define the similarities and the differences in these various, and often, overlapping domains. By dividing the field over and over, the ambiguity is only being increased, not resolved. Rather than building a core of graduates with a strong, shared foundation and multi-faceted capabilities, the multiple divides are building pockets of specialties. By dividing the potential workforce, the massive need for information-related professionals will not be handled.

\section{Current Educational Initiatives}

The definition of information literacy and the need for it has been identified by a variety of organizations such as the National Research Council (1999), American Library Association (1989; 2000), and the Information Technology Association of America (2000). Much more understanding of the spectrum of information literacy is required so that a clean paradigm shift can be made, from our current state of strife and confusion to a new set of well-defined, shared expectations across the culture. In 1989, the American Library Association (ALA) defined four aspects to information literacy:

1. The ability to recognize when information is needed;

2. The ability to locate the needed information;

3. The ability to evaluate the suitability of retrieved information, and

4. The ability to use effectively and appropriately the needed information. 
While these fours aspects are desirable competencies, they tend to cover a passive view of information handling, and not an active, generative view. When a generative perspective is applied to these four aspects, the notion of information literacy becomes much more tied to the underlying fields of mathematics, analysis, and programming.

The four abilities identified by the ALA are envisioned to be owned by every citizen within an information-intensive culture and must not be specialized to a subset of the population. The ability set starts with information literacy as characterized by the ALA and needs to be broadened to include basic analytical reasoning and model-based reasoning. Analytical reasoning encompasses the understanding of relationships among objects, the application of ordering principles to the objects, and the use of basic computational tasks relevant to the relationships and ordering (Educational Testing Service, 2000). Model-based reasoning encompasses (1) the ability to decompose systems, situations, and problems into basic inputs, processes and outputs, (2) the comprehension of control alternatives for a situation, and (3) the identification of valid operations within a situation (Russell and Norvig, 1995, p. 209).

Within an information-intensive culture, information systems - which would include all forms of computing systems - provide the opportunities to manifest analytical and model-based reasoning modes. Hence, a representation combining information literacy with information systems describes a situation where analytical reasoning and model-based reasoning can be applied.

Analytical reasoning and model-based reasoning are different from the skills invoked by the critical thinking programs present in primary and secondary education, and rolling into higher education classes. Basically, critical thinking involves the deductive reasoning processes. Critical thinkers evaluate the circumstances, terms, constraints, and behaviors of a situation in order to assess the degree of credibility of the situation. Critical thinking evaluates the static characteristics of a situation and does not involve an understanding of dynamic change or of mechanism. (See Ellis, 1998; Facione, 1996, or Ruggiero, 1996 for definitions of critical thinking.)

Analytical reasoning and model-based reasoning cover the range of skills from the ability to gather data about an environment, to an ability to understand cause and effect relationships, and ending with the ability to do deductive reasoning within an environment. Critical thinking is a primary component of analytical reasoning and model-based reasoning with model-based reasoning entailing more than both of the other two. One manifestation of these two reasoning modes is programming skills, i.e. the ability to transform a problem into a logically sequenced set of tasks within an environment, producing a change from an initial state into a final state.

\section{Contributions from Education Literature}

In the field of education, the hallmark description of how educational objectives can be defined and assessed is the Taxonomy of Educational Objectives, (Bloom, 1956), "Bloom's Taxonomy". A taxonomy provides a description for a related set of objects in terms of their natural relationships, features, and behaviors. Through the taxonomy, objects reveal their relationship to other objects by their juxtaposition in the ordering.

Bloom's Taxonomy identifies six levels of educational objectives:

1. Knowledge - “...involves the recall of specifics and universals, the recall of methods and processes, or the recall of a pattern, structure, or setting.... The knowledge objectives emphasize most the psychological processes of remembering" (Bloom, 1956, p.201).

2. Comprehension - "...refers to a type of understanding or apprehension such that the individual knows what is being communicated ... without necessarily relating it to other material or seeing its fullest implications" (Bloom, 1956, p. 204). 
3. Application - "...use of abstractions in particular and concrete situations" (Bloom, 1956, p. 205).

4. Analysis - “... the breakdown ... into its constituent elements or parts such that the relative hierarchy of ideas is made clear and/or the relations between the ideas expressed are made explicit" (Bloom, 1956, p. 205).

5. Synthesis - “...putting together of elements and parts so as to form a whole...involves the process of working with pieces, parts, elements, etc., and arranging and combining them in such as way as to constitute a pattern or structure not clearly there before" (Bloom, 1956, p. 206).

6. Evaluation - “...quantitative and qualitative judgments about the extent to which material and methods satisfy criteria" (Bloom, 1956, p. 207).

Bloom's Taxonomy is arranged from simple to complex behaviors, revealing a correspondence among the order of the levels to some "... 'real' order among the phenomena represented by the terms" (Bloom, 1956, p. 17). To validate the ordering proposition, studies of examination problems were made and support was obtained for the notion of an inherent progression in the classes of the taxonomy (Bloom, 1956, p. 18-20).

Bloom's Taxonomy has been used as a tool in educational descriptive efforts such as the development of the Information Systems-Centric Curriculum '99 (ISCC '99) (Lidtke, et al., 1999). Similarly, a defining structure for levels of information literacy, handling, and production provides a tool for industry to describe needed proficiencies and for educators to define program competencies.

\section{Taxonomy of Information Literacy Competencies}

To extend the applicability of Bloom's Taxonomy to the handling of information structures, the five fundamental units of information systems (Shelly et al., 1998, pp. 1.4-1.6) need to be mapped across the six levels of the educational objectives. The five units are:

1. Hardware - Physical components of a system

2. Software - Instruction sequences for a system

3. Data -- Static representations of system content

4. Procedures - Tasks and activities to be performed by people in conjunction with a system

5. People - Stakeholders of a system

Bloom's Taxonomy was devised to express educational objectives- "intended behaviors which the student shall display at the end of some period of education" (Bloom, 1956, p. 16). IT educational programs should express educational objectives relevant to information literacy competencies, e.g. intended behaviors in the context of information literacy which the student shall display at the end of some period of education.

The cross product of these two dimensions, education objectives and information systems, yields the following information literacy competency taxonomy (ILC taxonomy) shown in Table $\mathbf{1}$ below. For each entry in the matrix a sample question is presented which when answered correctly demonstrates mastery of that information literacy competency. 
LEVELS IN BLOOM'S TAXONOMY

\begin{tabular}{|c|c|c|c|c|c|c|}
\hline & Knowledge & Comprehension & Application & Analysis & Synthesis & Evaluation \\
\hline Hardware & $\begin{array}{l}\text { What are } \\
\text { the hard- } \\
\text { ware com- } \\
\text { ponents of } \\
\text { a system? }\end{array}$ & $\begin{array}{l}\text { What do the } \\
\text { components of } \\
\text { a hardware } \\
\text { system do? }\end{array}$ & $\begin{array}{l}\text { When } \\
\text { would the } \\
\text { hardware } \\
\text { suit my } \\
\text { needs? }\end{array}$ & $\begin{array}{l}\text { How } \\
\text { does } \\
\text { this } \\
\text { piece of } \\
\text { hard- } \\
\text { ware } \\
\text { work? }\end{array}$ & $\begin{array}{l}\text { How } \\
\text { would I } \\
\text { build this } \\
\text { hardware? }\end{array}$ & $\begin{array}{l}\text { What im- } \\
\text { proves } \\
\text { hardware } \\
\text { design? }\end{array}$ \\
\hline Software & $\begin{array}{l}\text { What are } \\
\text { the soft- } \\
\text { ware com- } \\
\text { ponents of } \\
\text { a system? }\end{array}$ & $\begin{array}{l}\text { What is the } \\
\text { role of soft- } \\
\text { ware is in a } \\
\text { system? }\end{array}$ & $\begin{array}{l}\text { When } \\
\text { would the } \\
\text { software fit } \\
\text { the situa- } \\
\text { tion? }\end{array}$ & $\begin{array}{l}\text { How } \\
\text { does } \\
\text { this } \\
\text { soft- } \\
\text { ware } \\
\text { work? }\end{array}$ & $\begin{array}{l}\text { How } \\
\text { would I } \\
\text { build this } \\
\text { software? }\end{array}$ & $\begin{array}{l}\text { What } \\
\text { conditions } \\
\text { produce } \\
\text { quality } \\
\text { software? }\end{array}$ \\
\hline Data & $\begin{array}{l}\text { Where can } \\
\text { I get data? }\end{array}$ & $\begin{array}{l}\text { What does this } \\
\text { data mean? }\end{array}$ & $\begin{array}{l}\text { When } \\
\text { would I } \\
\text { use this } \\
\text { data? }\end{array}$ & $\begin{array}{l}\text { How is } \\
\text { this } \\
\text { data } \\
\text { inter- } \\
\text { preted? }\end{array}$ & $\begin{array}{l}\text { How } \\
\text { would I } \\
\text { appropri- } \\
\text { ately } \\
\text { gather the } \\
\text { data? }\end{array}$ & $\begin{array}{l}\text { What fac- } \\
\text { tors in- } \\
\text { crease the } \\
\text { value and } \\
\text { reliability } \\
\text { of data? }\end{array}$ \\
\hline Procedure & $\begin{array}{l}\text { What ac- } \\
\text { tions can } \\
\text { be taken? }\end{array}$ & $\begin{array}{l}\text { What is the } \\
\text { purpose of an } \\
\text { action? }\end{array}$ & $\begin{array}{l}\text { When } \\
\text { would an } \\
\text { action oc- } \\
\text { cur? }\end{array}$ & $\begin{array}{l}\text { What } \\
\text { are the } \\
\text { steps of } \\
\text { the ac- } \\
\text { tion? }\end{array}$ & $\begin{array}{l}\text { How } \\
\text { would I } \\
\text { define the } \\
\text { steps of } \\
\text { the action? }\end{array}$ & $\begin{array}{l}\text { Which } \\
\text { aspects of } \\
\text { an action } \\
\text { are neces- } \\
\text { sary and } \\
\text { which are } \\
\text { sufficient? }\end{array}$ \\
\hline People & $\begin{array}{l}\text { Who are } \\
\text { the stake- } \\
\text { holders? }\end{array}$ & $\begin{array}{l}\text { What are the } \\
\text { roles and rela- } \\
\text { tionships of } \\
\text { individuals in a } \\
\text { situation? }\end{array}$ & $\begin{array}{l}\text { When } \\
\text { should an } \\
\text { individual } \\
\text { become } \\
\text { involved? }\end{array}$ & $\begin{array}{l}\text { How is } \\
\text { the per- } \\
\text { son re- } \\
\text { spond- } \\
\text { ing? }\end{array}$ & $\begin{array}{l}\text { How can } \\
\text { the indi- } \\
\text { viduals } \\
\text { have their } \\
\text { responses } \\
\text { changed? }\end{array}$ & $\begin{array}{l}\text { What sig- } \\
\text { nificance } \\
\text { does an } \\
\text { individual } \\
\text { have to } \\
\text { the pro- } \\
\text { gress of a } \\
\text { system? }\end{array}$ \\
\hline
\end{tabular}

Table 1: The "information literacy competency" taxonomy. 
The space of the ILC taxonomy is the cross product of objective $::\{1=$ Knowledge $\ldots 6=$ Evaluation $\}$ and information system aspect, $I S$-aspect, $::\{1=$ Hardware ... $5=$ People), yielding the 30 cells shown in Table 1. For a curriculum, each cell has a degree, identifying the duration or frequency of the curriculum's coverage of the concepts indicated by the cell. A curriculum can be represented by assigning each cell a number, between 0 and 1, with 0 implying no coverage and 1 implying significant coverage. Then, the relationship connecting a curriculum, objective, IS-aspect and degree is :

$$
\text { Curriculum } \equiv F\left(\text { degree }_{\text {objective, IS-aspect }}\right)
$$

\section{Applications of the "Information Literacy Competency" Taxonomy}

The ILC taxonomy, spanning the fundamental units of information systems, offers a constructionist approach for defining ranges of information literacy competency. With this approach, disciplines express a degree of fluency appropriate for their field. Once the amount of fluency is specified, then individuals can be trained to meet discipline-specified needs and not simply to be trained.

For example, IT certification programs might be differentiated from IT university programs by the fact that IT university programs generally span - have a presence in -- all five facets of Bloom's Taxonomy while the certification programs may not. The cells where the IT program has a presence identify the content emphasis of the IT program.

Other possible expressions of information literacy competency relative to a curriculum are shown below as examples of the use of the taxonomy. The diagrams are not intended to express the nature of each and every instance of the program, but rather to express the nature for a specific program. The shading of the cells expresses the degree or weight placed on the relevant cell; dark cells represent significant coverage, light cells little or no coverage. The cells are arranged in the same order as expressed in Table 1.

- Primary and secondary information-literacy education:

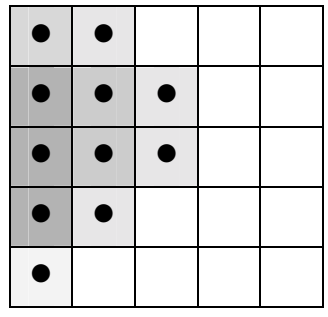

- Computer Engineering, undergraduate:

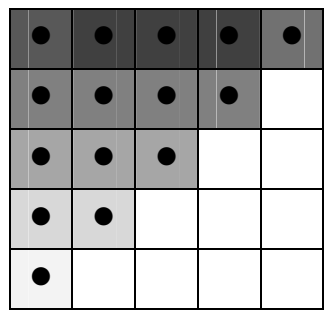


- Management Information Systems, undergraduate:

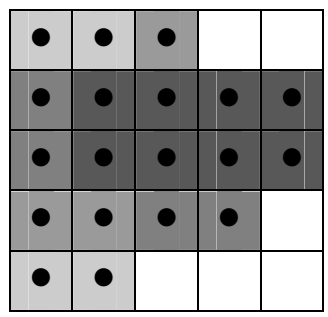

- Vendor-specific network certification:

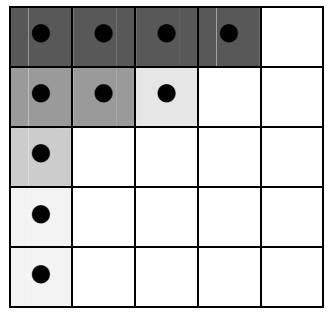

Using the ILC taxonomy with the degree of coverage, newly proposed programs can be evaluated against on-going or alternative approaches. The visualization can be used by decision-makers to answer the question, "Is this new program substantially different in its content from our existing programs?" Revisions to curriculums can be reviewed in terms of the ILC taxonomy in order to describe the change in terms of expected changes in "information literacy competency" behaviors.

\section{Conclusion}

Innately, information processing has always been an expression of humankind's interaction with its environment. As our environment has become more complex, the need to handle information appropriately, efficiently, and verifiably has grown. In fact, each nation can define the ideal information literacy competency matrix desired for its citizens, and then promote the activities to realize those information literacy objectives. Nations desiring their citizens to express greater abilities with the synthesis and evaluation of information would also enable these objectives by stressing analytical and model-based reasoning modes as part of the learning in each and every educational program.

While the ALA's definition of information literacy is a reasonable beginning for understanding the facets of information literacy, the statement does not go far enough. The ILC taxonomy encompasses the aspects for analytical reasoning as well as for model-based reasoning by considering the aspects of information systems in conjunction with the higher levels of Bloom's Taxonomy, namely the levels of Application, Analysis, Synthesis, and Evaluation. This richer representation of information literacy by the ILC taxonomy provides a tool for objectively characterizing academic programs.

The ILC taxonomy, spanning the fundamental units of information systems, offers a constructionist approach for defining ranges of information literacy. With this approach, professionals of a discipline can express a degree of fluency appropriate for their field. Once the amount of fluency has been specified, then individuals can be trained to meet discipline-specified needs and not simply to be trained.

\section{References}

Association of College and Research Libraries, American Library Association. (2000). Information Literacy Competency Standards for Higher Education. Chicago: Author.

American Library Association. (1989). Presidential Committee on Information Literacy: Final Report. Chicago: Author. 
Taxonomy of Information Literacy Competencies

Bloom, B. S. (Ed.) $(1984,1956)$. Taxonomy of Educational Objectives. Handbook 1; Cognitive Domain. New York: Longman.

Business Coalition for Excellence in Education. (2000). Principles for K-12 Education Legislation. Washington, D.C.: Author. Retrieved March 7, 2001 from the World Wide Web http:/Www.itaa.org/workforce/bcee/.pdt

Clark, D. (2000). “Are Too Many Programmers Too Narrowly Trained?” Computer, June and July. Retrieved August 25, 2000 from the World Wide Web nttp://computer.org/computer/articles/June_and_July/trends600.htm

Ellis, D. (1998). Becoming a Master Student. ( $8^{\text {th }}$ ed.). Boston: Houghton Mifflin.

Facione, P. (1996). Critical Thinking: What It Is and Why It Counts. Millbrae, CA: California Academic Press.

Education Testing Service. (2000). GRE Analytical Reasoning Questions. Princeton, NJ: Author. Retrieved July 26, 2001 from the World Wide Web http:/Www.gre.org/practice_test/takear.htm

Hancock, V. E. (1993). “Information Literacy for Lifelong Learning,” ERIC Digest, ERIC Clearing House on Information Resources. Syracuse, NY. ERIC Identifier: ED358870. Retrieved May 30, 2000 from the World Wide Web http://www.edd.gov/databases/ERIC Digetst/ed358870.htm

Information Technology Association of America. (2000). Executive Summary - Bridging the Gap: Information Technology Skills for a New Millennium. Retrieved March 7, 2001 from the World Wide Web nttp://www.itaa.org/workforce/studies/hwooexecsumm.htm

Information Technology Association of America. (1996). Help Wanted 1998: A Call for Collaborative Action for the New Millennium. Retrieved March 7, 2001 from the World Wide Web http://www.itaa.org/workforce/studies/hw98.htm

Information Technology Association of America. (1996). Help Wanted: The IT Workforce Gap at the Dawn of a New Century. Arlington, VA: Author.

Lidtke, D. D., Stokes, Gordon E., Haines, Jimmie, \& Mulder, Michael C. (Eds.) (1999). ISCC '99: An Information SystemsCentric Curriculum '99: Program Guidelines for Educating the Next Generation of Information Systems Specialists, in Collaboration with Industry. (Contract Nos. DUE/CIS 9352944, DUE 9455450, and DUE 9796243). Washington, D.C.: National Science Foundation.

National Research Council. Commission on Physical Sciences, Mathematics, and Applications. Committee on Information Technology Literacy, Computer Science and Telecommunications Board. (1999). Being Fluent with Information Technology. Publication. Washington, D.C.: National Academy Press.

Russell, Stuart J. \& Norvig, Peter. (1995). Artificial Intelligence: A Modern Approach. Upper Saddle River, NJ: Prentice Hall.

Ruggiero, V. R. (1996). Becoming a Critical Thinker. Boston: Houghton Mifflin.

Shachtman, N. (1998). “Next-Level Web, “Information Week, September 28, pp. 140-146.

Shelly, G. B., Cashman, T. J., \& Rosenblatt, H. J. (1998). Systems Analysis and Design (3 ${ }^{\text {rd }}$ ed.). Cambridge, MA: Course Technology.

Smith, A. (Downloaded 2000). “Information Literacy,” Retrieved May 30, 2000 from the World Wide Web nttp.//inst.augie.edu/ asmith/infolit.htm

Tadjer, R. (1998). “Career Changes,” Network World, 15(46), November 16, p. 67.

U.S. Department of Commerce. (January 1998). Update: America's New Deficit: The Shortage of Information Technology Workers." Washington, D.C.: Author.

U.S. Department of Commerce, Office of Technology Policy. (1997). America's New Deficit: The Shortage of Information Technology Workers. Washington, D.C.: Author.

Wurman, R. S. (1989). Information Anxiety. New York: Doubleday. 


\section{Biographies}

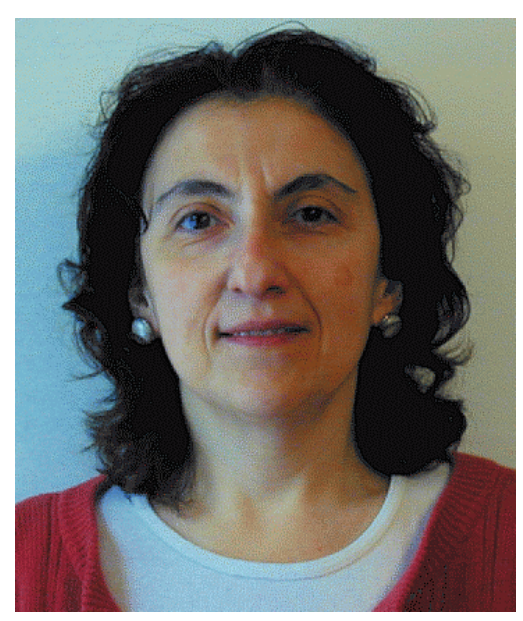

T. M. Vitolo received the B.S.E. degree in industrial engineering and $\mathrm{Ph}$.D. degree in information science from University of Pittsburgh in 1978 and 1985, respectively. Teaching in systems-related fields since 1985, she joined the Computer and Information Science Department at Gannon University in 1999. In addition to teaching, she has worked as a systems analyst / programmer on a variety of systems development projects. Her interests include intelligent interface design, motivated system energetics, and other issues in the field of human-computer interactions.

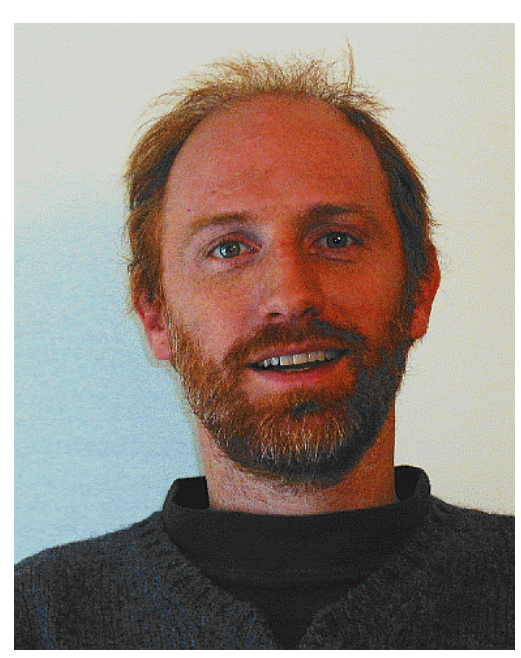

C. Coulston received the B.S., M.S., and Ph.D degrees in computer science and engineering from The Pennsylvania State University in 1991, 1994 and 1999, respectively. In 1999 he joined the Electrical and Computer Engineering Department at Penn State Erie, The Behrend College where he is currently an Assistant Professor. His research interests are in teaching methodologies, hypertext metrics, and computational complexity. 